\title{
Plant Regeneration from Protoplasts Derived from Callus of Phalaenopsis
}

\author{
Shunjin Kobayashi*, Toshiaki Kameya** and Syoichi IchIHASHI*** \\ *Plant Biotechnology and Research Laboratory, Tohoku Oil Co., Ltd., Sendai, 985 Japan \\ **Institute of Genetic Ecology, Tohoku University, Sendai, 980 Japan \\ ${ }^{* * *}$ Department of Life Science, Aichi University of Education, Kariya, Aichi, 448 Japan
}

(Received April 1, 1993)

(Accepted August 26, 1993)

The isolation, culture, and plant regeneration of protoplasts derived from callus of Phalaenopsis was established. Callus was obtained by the culture of a lateral bud on a young flower stalk. Protoplasts were isolated enzymatically from callus which was precultured on $\mathrm{P}$ basal medium (without coconut water (CW) and sucrose) for 30 days. The first cell division was observed after 7-10 days of culture in the basal medium supplemented with 2, 4-dichlorophenoxyacetic acid (2, 4-D) or CW. After 60 days of culture, the protoplasts cultured in the medium supplemented with $0.05-0.1 \mathrm{mg} / \mathrm{l} 2,4-\mathrm{D}$ and $10 \%(\mathrm{v} / \mathrm{v}) \mathrm{CW}$ formed numerous colonies by the addition of fresh medium. The colonies developed into small calli and turned green under continuous light condition, and small calli produced PLBs in the same liquid medium. The PLBs derived from protoplasts regenerated shoots readily on $\mathrm{P}$ basal regeneration medium $(10 \%(\mathrm{v} / \mathrm{v}) \mathrm{CW}, 0.3 \%(\mathrm{w} / \mathrm{v})$ Gelrite). The shoots developed into whole plants after transfer onto Hyponex medium $(3 \mathrm{~g} / l$ Hyponex (N:P:K, 6. 5:6:19), 2. $0 \%(\mathrm{w} / \mathrm{v})$ sucrose, 0.05\% (w/v) activated charcoal, $0.3 \%(\mathrm{w} / \mathrm{v})$ Gelrite).

\section{Introduction}

Regeneration of plants from protoplasts is one of the essential techniques for improving plants through somatic hybridization or genetic transformation. Efficient systems of micropropagation using tissue culture techniques have been accomplished in many orchids ${ }^{1)}$. However, reports on plant regeneration from protoplasts of orchids are very few. In this paper, we describe the plant regeneration from callus-derived protoplasts of Phalaenopsis.

\section{Materials and Methods}

\section{Callus induction and culture}

Callus $^{2)}$ was obtained by the culture of a lateral bud on a young flower stalk of Phalaenopsis hybrid (Phalaenopsis (Grand City $\times$ Texas Thunder) $\times$ Phalaenopsis (Mikawa White $\times$ Wataboushi)). To select friable yellow callus, callus was subcultured on $\mathrm{P}$ basal medium ${ }^{3)}$ supplemented with $15 \%$ (v/ v) coconut water (CW) $2.0 \%(\mathrm{w} / \mathrm{v})$ sucrose and $0.3 \%(\mathrm{w} / \mathrm{v})$ Gelrite (Fig. 1-A).

\section{Protoplast isolation and culture}

Prior to protoplast isolation the friable yellow callus was transferred onto $\mathrm{P}$ basal medium supplemented with $0.3 \%(\mathrm{w} / \mathrm{v})$ Gelrite (without $\mathrm{CW}$ and sucrose) and precultured at $25^{\circ} \mathrm{C}$ in con-

Present Address : Research Laboratory for Development, Mitsubishi Oil Co., Ltd., 4-1, Ohgimachi, Kawasaki-ku, Kawasaki, 210 Japan 
tinuous light (2, 500 lux provided by cool white fluorescent lamps). After 30 days of preculture, the callus was incubated in an enzyme solution $(1.0 \%(\mathrm{w} / \mathrm{v})$ Cellulase Onozuka RS, $0.1 \%(\mathrm{w} / \mathrm{v})$ Driserase, $0.1 \%(\mathrm{w} / \mathrm{v})$ Pectlyase Y-23, $0.1 \%(\mathrm{w} / \mathrm{v}) \mathrm{CaCl}_{2} \cdot 2 \mathrm{H}_{2} \mathrm{O}, 5.5 \%(\mathrm{w} / \mathrm{v})$ sorbitol, $\mathrm{pH}$ 5. 5) for $2 \mathrm{hr}$ at $25{ }^{\circ} \mathrm{C}$ on a reciprocal shaker ( 40 strokes $/ \mathrm{min}$.). The enzyme-protoplast mixture was passed through a nylon sieve of $32 \mu \mathrm{m}$ pore size to remove undigested cell clumps. The protoplasts were collected by centrifugation at $100 \times \mathrm{g}$ for $3 \mathrm{~min}$. and washed three times with a washing solution $(0.1 \%(\mathrm{w} / \mathrm{v})$ $\mathrm{CaCl}_{2} \cdot 2 \mathrm{H}_{2} \mathrm{O}, 5.5 \%$ (w/v) sorbitol). Then they were overlayed onto a $15 \%(\mathrm{w} / \mathrm{v})$ Ficoll solution and centrifuged at $100 \times \mathrm{g}$ for $3 \mathrm{~min}$. The protoplasts floating on the Ficoll solution were collected and washed once with a washing solution.

Protoplasts were cultured at the density of $0.5-1.0 \times 10^{5} / \mathrm{ml}$ in $30 \times 15 \mathrm{~mm}$ plastic petri dish with one $\mathrm{m} l$ liquid medium consisting of $\mathrm{P}$ basal medium supplemented with $5.5 \%(\mathrm{w} / \mathrm{v})$ sorbitol and various concentrations of 2, 4-dichlorophenoxyacetic acid $(2,4-\mathrm{D})$ with or without $10 \%(\mathrm{w} / \mathrm{v}) \mathrm{CW}$. The dishes were placed in a plastic box and cultured at $25^{\circ} \mathrm{C}$ in the dark. After 20 days of culture, $0.5 \mathrm{~m} l$ fresh medium was added to the culture dish. After 30 days of culture, the cultures were diluted 2 times with the same liquid medium supplemented with $4.5 \%(\mathrm{w} / \mathrm{v})$ sorbitol. One $\mathrm{m} l$ of the same liquid medium $(4.5 \%(\mathrm{w} / \mathrm{v})$ sorbitol) was added every 15 days and the dishes were placed under continuous light (2,500 lux provided by cool white fluorescent lamps) at $25^{\circ} \mathrm{C}$ for PLB formation after 60 days of culture. When protoplast-derived PLBs became about $2 \mathrm{~mm}$ in diameter, they were transferred onto the regeneration medium consisting of $\mathrm{P}$ basal medium, $10 \%(\mathrm{v} / \mathrm{v}) \mathrm{CW}$ and $0.3 \%(\mathrm{w} / \mathrm{v})$ Gelrite. When the PLBs regenerated shoots, they were transferred onto Hyponex medium (3 g/l Hyponex (N:P:K, 6. 5:6:19) , 2.0\% (w/v) sucrose, 0.05\% (w/v) activated charcoal, 0. $3 \%(\mathrm{w} / \mathrm{v})$ Gelrite) for shoot development and root fromation.

\section{Results and Discussion}

While the callus was precultured on $\mathrm{P}$ basal medium $(0.3 \%(\mathrm{w} / \mathrm{v})$ Gelrite $)$, the color of callus turned green gradually (Fig. 1-B). The average yield of protoplasts from these green callus was $3 \times$ $10^{5}$ per $\mathrm{g}$ of callus after the whole washing procedure (Fig. 1-C). The first division was observed after 7-10 days of culture in the culture medium supplemented with 2, 4-D or CW (Fig. 1-D, Table 1). Both 2, 4-D and CW were effective for cell division, but higher concentrations of 2, 4-D inhibited cell division. The greatest frequency of cell division (7-8\%) was observed in the culture medium supplemented with $0.05 \mathrm{mg} / \mathrm{l} 2,4-\mathrm{D}$ and $10 \%(\mathrm{v} / \mathrm{v}) \mathrm{CW}$. The protoplasts cultured in the medium supplemented with 2, 4-D and CW formed colonies (Table 1). Especially, in the medium containing both $0.05-0.1 \mathrm{mg} / l 2,4-\mathrm{D}$ and $10 \%(\mathrm{v} / \mathrm{v}) \mathrm{CW}$, cells divided vigorously and numerous colonies formed within 30 days. The addition of $2,4-\mathrm{D}$ to the culture medium was essential to colony formation, because no colonies was observed in the culture medium without 2, 4-D. Supplement of CW to the medium seemed to increase the rate of colony formation. Sajise et $a l .{ }^{4}$ reported plant regeneration from the protoplasts of Phalaenopsis which were derived from calli similar to what we used. Although they observed colony formation in basal medium supplemented only with $\mathrm{CW}$, in this study the plant growth regulator $2,4-\mathrm{D}$ was apparently more important than $\mathrm{CW}$ for colony formation.

While the colonies grew slowly, they became visible after 60 days (Fig. 1-E). Then the petri dishes were transferred to continuous light condition, and the colonies developed into small calli and turned green. PLB differentiated from greenish calli in the same liquid medium. When protoplastderived PLBs were placed on P basal regeneration medium (10\% (v/v) CW, $0.3 \%(\mathrm{w} / \mathrm{v})$ Gelrite), shoots were readily regenerated from them within one month (Fig. 1-F) and secondary PLBs often 


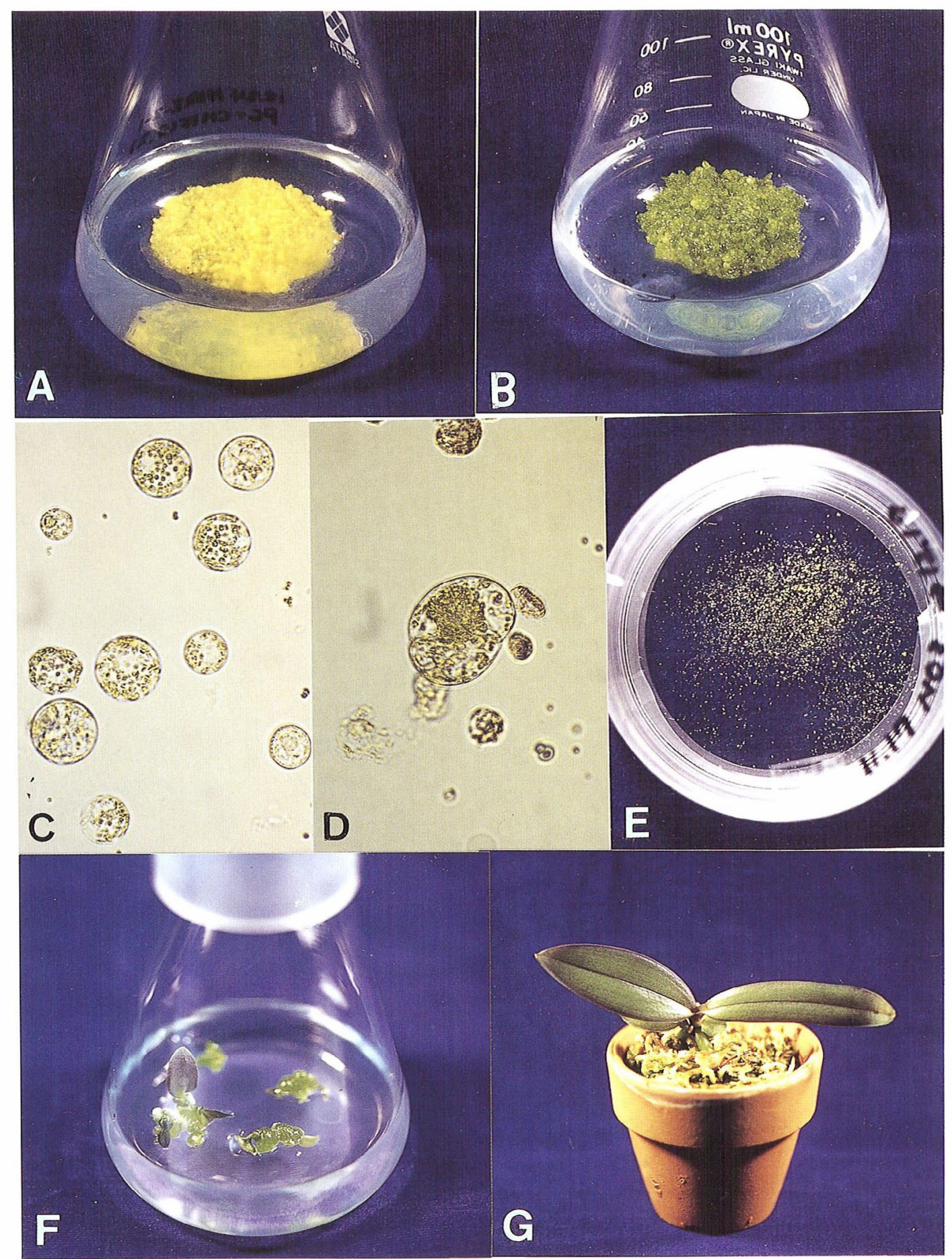

Fig. 1 Plant regeneration from callus-derived protoplasts of Phalaenopsis.

A : Calli of Phalaenopsis on P basal medium supplemented with $10 \%(\mathrm{v} / \mathrm{v}) \mathrm{CW}$ and $2.0 \%(\mathrm{w} / \mathrm{v})$ sucrose. B : Green calli after 30 days of preculture on $\mathrm{P}$ basal medium (without $\mathrm{CW}$ and sucrose). C : Freshly isolated protoplasts from green calli. D : The first cell division 7 days after protoplast culture. E : Cell colonies from protoplasts about 60 days after protoplast culture. F : Shoot regeneration from protoplast-derived PLB on $\mathrm{P}$ basal medium supplemented with $10 \%(\mathrm{v} / \mathrm{v}) \mathrm{CW}$. $\mathrm{G}$ : A regenerated whole plant from protoplast-derived PLB in a pot with sphagnaum moss. 
Table 1. Effect of 2,4-D and coconut water (CW) on cell division and colony formation from Phalaenopsis protoplasts.

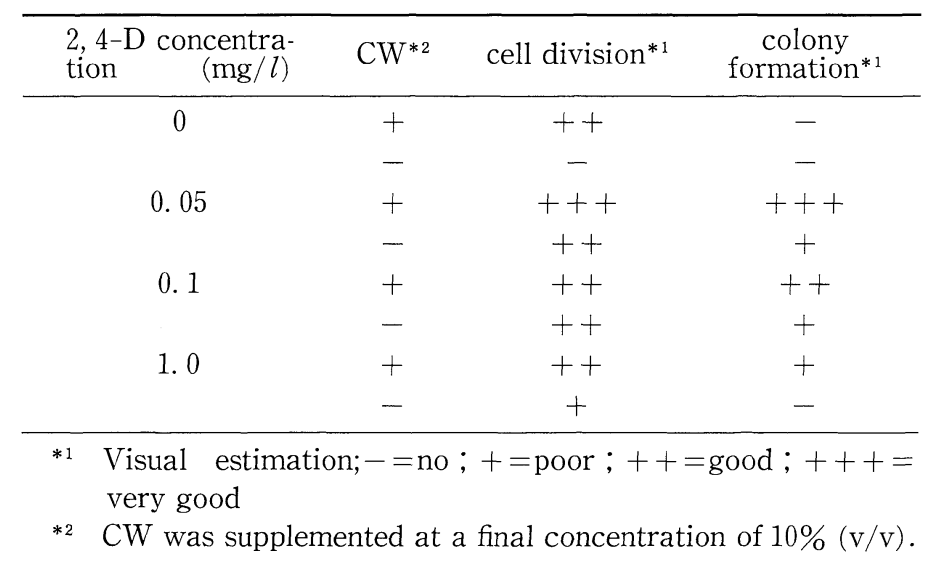

formed. The PLBs, which regenerated shoots, produced roots after they were transferred onto Hyponex medium $(3 \mathrm{~g} / l$ Hyponex $(\mathrm{N}:$ P: K, $6.5: 6: 19), 2.0 \%(\mathrm{w} / \mathrm{v})$ sucrose, $0.05 \%(\mathrm{w} / \mathrm{v})$ activated charcoal, $0.3 \%(\mathrm{w} / \mathrm{v})$ Gelrite). Regenerated plants were transplanted into pots with sphagnaum moss (Fig. 1-G).

Generally, plant regeneration from protoplasts of orchid was very difficult. Though we tried previously to culture Phalaenopsis protoplasts from PLBs or leaf segments, the protoplasts never formed colonies. Hawever, in this study, we could establish a plant regeneration system from protoplasts in Phalaenopsis.

Although further work is necessary to enhance regeneration frequency from protoplasts of Phalaenopsis, this study provides an experimental basis for studies on somatic hybridization and genetic transformation in Phalaenopsis.

\section{Acknowledgement}

We thank Miss M. Nomura for her help in culturing protoplasts and all members of plant Biotechnology and Research Laboratory, Tohoku Oil Co., Ltd., for their helpful discussions.

\section{References}

1) Pierik, R. L. M., 1987. In “In vitro culture of higher plant”, p. 159-167, Martius Nijhoff Publishers, Dordrecht.

2) Ichihashi, S., 1992. Lindleyana, 7: 208-215.

3) Ichihashi, S., H. Hiraiwa, 1992. J. Japan. Soc. Hort. Sci., 61: 456-457 (in Japanese).

4) Sajise, J. U., Y. Sagawa, 1990. In "Proc. Nagoya Int. Orchid Show '90" (eds. Ichihashi, S., H. Nagata), p. 84-89. 


\title{
《和文要約》
}

コチョウラン (Phalaenopsis) のカルス由来プロトプラストからの植物体再生

\author{
小林俊仁*・亀谷寿昭 $* *$ 市橋正一*** \\ *東北石油株式会社植物バイオ研究室 \\ 現：三菱石油株式会社開発研究所 \\ **東北大学遺伝生態研究センター \\ ***愛知教育大学生命科学領域
}

コチョウランのカルス由来プロトプラストの単離および植物体再生について検討した．材料としたカルス は, 若い花茎の腋芽培養によって形成される微細な粒状組織を選抜移植して, 継代増殖することによって得 られた。このカルスをシュークロースとココナッツウォーター $(\mathrm{CW})$ を除いた $\mathrm{P}$ 基本培地で前培養した。 30 日前培養後, 緑化したカルスを $1.0 \%$ セルラーゼ “オノッ゙カ” RS, $0.1 \%$ ドリセラーゼ， $0.1 \%$ ペクトリ アーゼ $\mathrm{Y}-23,0.1 \% \mathrm{CaCl}_{2} \cdot 2 \mathrm{H}_{2} \mathrm{O}, 5.5 \%$ ソルビトールの酵素液で 2 時間処理し, プロトプラストを単離した. 精製したプロトプラストを $2,4-\mathrm{D}$ を 0-1.0 mg/l 添加し，10\% ココナッツウォーター (CW) を含む，また は含まない $\mathrm{P}$ 基本培地で培養した。プロトプラストは培養後 7-10日に分裂を開始し，その分裂には 0.05 $\mathrm{mg} / l 2,4-\mathrm{D}$ と $\mathrm{CW}$ を添加した培地が最も効果的であった。 その後新鮮培地を添加していくことによって, 0.05-0.1 mg/lの 2, 4-D と CW を添加した培地では，60 日後には多数のコロニーを形成した．同培地でコ ロニーを連続照明下で培養するとカルスへと発達し，緑化後，PLB を形成した。プロトプラスト由来の PLB は P 基本培地 (10\% CW 添加) で容易にシュートを分化し，さらにハイポネックス培地に移植すると 発根して植物体が再生した。 